\title{
DEVELOPMENT OF Coleomegilla maculata DE GEER (COLEOPTERA: COCCINELLIDAE) WITH PREY AND ARTIFICIAL DIET
}

\author{
RAFAEL BRAGA DA SILVA ${ }^{1}$, IVAN CRUZ², MARIA DE LOURDES CORRÊA \\ FIGUEIREDO $^{2}$ and WAGNER DE SOUZA TAVARES ${ }^{3}$
}

\begin{abstract}
${ }^{1}$ Universidade Federal de São Carlos, CEP: 13.565-905, São Carlos, SP, Brasil, E-mail: rafaelentomologia@yahoo.com.br

${ }^{2}$ Embrapa Milho e Sorgo, CEP: 35.701-970, Sete Lagoas, MG, Brasil, E-mail:ivancruz@cnpms.embrapa.br,figueiredomlc@yahoo.com.br ${ }^{3}$ Universidade Federal de Viçosa, CEP: 36.570-000, Viçosa, MG, Brasil, E-mail:wagner.tavares@ufv.br
\end{abstract}

Revista Brasileira de Milho e Sorgo, v.9, n.1, p. 13-26, 2010

\begin{abstract}
Coleomegilla maculata De Geer (Coleoptera: Coccinellidae) is an important predator and has the potential to be used as a biological control agent of insect pests of maize (Zea mays L.) and sorghum [Sorghum bicolor (L.) Moench]. This study aimed to evaluate the development of C. maculata larvae fed eggs Anagasta kuehniella (Zeller) (Lepidoptera: Pyralidae) alone or associated with artificial diet, eggs of Spodoptera frugiperda (J. E. Smith) (Lepidoptera: Noctuidae) and nymphs of Schizaphis graminum (Rondani) (Hemiptera: Aphididae). The experiment was conducted in a complete randomized design with four replications, each with 10 larvae of $C$. maculata in an acclimatized room $\left(25 \pm 1{ }^{\circ} \mathrm{C}, 70 \pm 10 \% \mathrm{RH}\right.$ and 12 hours photophase). The duration of the stages of $C$. maculata was similar in all treatments, except for one that used nymphs of $S$. graminum, resulting in a shorter period for the larval stage. The viability of larval, prepupal and pupal stages and larval to adult $C$. maculata was high and similar in all treatments. No effect of diets on the weight of $C$. maculata adults occurred, except for the heavier insects fed on eggs of A. kuehniella, whose males and females weighed $9.8 \pm 0.3 \mathrm{mg}$ and $13.3 \pm 0.5 \mathrm{mg}$, respectively.
\end{abstract}


Therefore, based on laboratory results, the predator can be evaluated in the field in pest management program against $S$. frugiperda and $S$. graminum. Advance in the methodology of rearing the predator in the laboratory can be obtained through the use of artificial diet (honey, yeast, ascorbic acid, propionic acid, nipagin and water) associated with eggs of $A$. kuehniella.

Key words: biological control, fall armyworm, aphids, lady beetles, rearing methodology.

\section{DESENVOLVIMENTO DE Coleomegilla maculata DE GEER (COLEOPTERA: COCCINELLIDAE) COM PRESAS E DIETA ARTIFICIAL}

RESUMO - Coleomegilla maculata De Geer (Coleoptera: Coccinellidae) é um predador importante e com potencial para o controle biológico de insetos-praga de milho (Zea mays L.) e de sorgo [Sorghum bicolor (L.) Moench]. Este trabalho teve como objetivo avaliar o desenvolvimento de larvas de C. maculata alimentadas com ovos de Anagasta kuehniella (Zeller) (Lepidoptera: Pyralidae), isoladamente ou associados à dieta artificial, ovos de Spodoptera frugiperda (J. E. Smith) (Lepidoptera: Noctuidae) e ninfas de Schizaphis graminum (Rondani) (Hemiptera: Aphididae). O delineamento estatístico foi inteiramente casualisado, com seis tratamentos e quatro repetições, sendo cada uma composta por 10 larvas de C. maculata, em sala climatizada $\left(25 \pm 1{ }^{\circ} \mathrm{C}, 70 \pm 10 \%\right.$ UR e fotofase de 12 horas). A duração dos estádios de C. maculata foi semelhante em todos os tratamentos, à exceção daquele em que foram utilizadas ninfas de $S$. graminum, resultando em menor período para o estádio larval. A viabilidade do estádio larval, pré-pupal, pupal e de larva a adulto de $C$. maculata foi alta e semelhante em todos os tratamentos. Não houve efeito das dietas sobre o peso de insetos, exceto para aqueles que se alimentaram com ovos de $A$. kuehniella, cujos machos e fêmeas pesaram 9,8 $\pm 0,3 \mathrm{mg}$ e 13,3 $\pm 0,5 \mathrm{mg}$, respectivamente. Portanto, pelos resultados de laboratório, o predador pode ser avaliado no campo, em programas de manejo, visando tanto $S$. frugiperda, quanto $S$. graminum. Avanços na metodologia de criação deste inseto pode ser obtido através do uso de dieta artificial (mel, levedo de cerveja, ácido ascórbico, ácido propiônico, nipagin e água) associada a ovos de A. kuehniella.

Palavras-chave: controle biológico, lagarta-do-cartucho, pulgões, joaninhas, metodologia de criação.

Revista Brasileira de Milho e Sorgo, v.9, n.1, p. 13-26, 2010

Versão impressa ISSN 1676-689X / Versão on line ISSN 1980-6477 - http://www.abms.org.br 
Many studies have been conducted to establish nutritional needs, environmental condition and potentiality as biocontrol agents of entomophagous insects (Thompson, 1999).

The knowledge of the biology, behavior and breeding techniques can improve the potential of predatory insects, but food suitability in laboratory rearing still represents major limitation toward the use of Coccinellidae aphidophagous as biological control agent (Kato et al., 1999ab; Silva et al., 2009).

Coleomegilla maculata De Geer (Coleoptera: Coccinellidae) is a polyphagous cosmopolitan species (Munyaeza \& Obrycki, 1998) with a great potential to be used in integrated pest management programs due to some outstanding qualities such as highly biotic potential and predation habit in both larval and adult stage.

Diets based on pig liver have been developed for predators. Coleomegilla maculata was one of the first species to produce fertile offspring under in vitro conditions. Viability around 86 percent was obtained from insect larvae reared on raw pork liver based artificial diet and vitamin supplement (Attallah \& Newson, 1966). Fresh pig liver has been also suitable for rearing other Coccinellidae species, including Adalia bipunctata (L.), Coccinella septempunctata (L.), Coccinella transversoguttata ricardsoni (Brown), Hippodamia tredecimpunctata tibialis (Say) and Propylea quatuordecimpunctata (L.) (Kariluoto et al., 1976; Kariluoto, 1980). Semi defined diets, without meat, but supplemented with insect preys have been evaluated to rear species of Coccinellidae (Attallah \& Newson, 1966; Kariluoto, 1980; Matsuka et al., 1982, Silva et al., 2009). Alternative food such as eggs of Anagasta kuehniella (Zeller) (Lepidoptera: Pyralidae) has been considered as a replacement of natural prey for Coccinellidae due to low production cost and suitability in rearing procedures (Kato et al., 1999ab; Silva et al., 2009).

Larval or adult food source can influence the biological aspects of insects, such as fecundity and fertility. For example, artificial diets based on carbohydrate solution although enabled the maintenance of adult Coccinellidae, drastically reduce the female fecundity (Hagen, 1962). Easy disposability and nutritional suitability for larvae and adult development are essential to progressing in biological control program using Coccinellidae species, considering the wide range of consumed preys (Hodek, 1973).

Quantity and quality of food can influence the physiological status of females of the genus Hippodamia (Coleoptera: Coccinellidae) (Hodek, 1967). For example, Hippodamia convergens Guérin-Méneville (Coleoptera: Coccinellidae) requires the amino acid cystine to normal pupation and metamorphosis (Racioppi et al., 1981). The lack of such compound could explain female infecundity when feed only on eggs of A. kuehniella (Kato et al., 1999b).

Coleomegilla maculata has its development influenced by food source (Hodek, 
1973). Faster development and higher survival rates were obtained when the insect received as food source a mix of corn leaf aphid, Rhopalosiphum maidis (Fitch) (Hemiptera: Aphididae) and maize (Zea mays L.) pollen than with only one of these sources (Cottrell \& Yeargan, 1998; Lundgren \& Wiedenmann, 2004).

Production system can affect the efficiency of predator. Predation rate of C. maculata on eggs of Ostrinia nubilalis (Hübner) (Lepidoptera: Pyralidae) was higher in a monoculture corn than in maize/beans/ squash mixed production system (Andow \& Risch, 1985). This was explained by the fact that predators spend more time foraging on plants without prey (beans and squash), which decreases their efficiency (Risch et al., 1983). Coleomegilla species were observed feeding on young larvae of Spodoptera frugiperda (J. E. Smith) (Lepidoptera: Noctuidae) in maize (Hoballah et al., 2004). Eggs of S. frugiperda also can be a food source for C. maculata on maize plants (Pereira, 1997). Spodoptera frugiperda is a key pest of maize in America and can limit the yield of maize plants.

In general, aphids are recognized as a preferential prey for Coccinelidae. Two important aphid species in South America agribusiness are associated to maize and sorghum, Sorghum bicolor (L.) Moench plants: the corn leaf aphid, $R$. maidis and the greenbug, Schizaphis graminum (Rondani) (Hemiptera: Aphididae).
Rhopalosiphum maidis occurs in economically important crops such as barley (Hordeum vulgare L.), oats (Avena sativa L.), rye (Secale cereale L.), sugar cane (Saccharum officinarum L.), wheat (Triticum vulgare Vill.), maize and sorghum, and can survive in wild Poaceae. Intense attacks of this insect can cause direct damage to host plant by sucking sap, affecting the quality of seeds (Maia et al., 2005; Fonseca et al., 2006). This insect is a vector of several diseases, caused mainly by viruses (Stoetzel \& Miller, 2001), such as dwarf mosaic in sugar cane, maize and sorghum and the common mosaic, considered among the most important disease in maize in Brazil (Fonseca et al., 2006).

Sorghum is the preferred host of $S$. graminum, but this aphid can attack various other grasses, with the damage characterized by large amount of sap extracted which limits the supply of water and nutrients. In the process of feeding, S. graminum injects toxin, which causes enzymatic destruction of the cell wall of leaves, causing chlorosis and finally necrosis. Besides the direct damage, the insect can transmit viruses or predispose the plant to stem rot and the depreciation of the grains (Cruz \& Vendramim, 1989).

The objective of this study was to identify a suitable diet for rearing $C$. maculata in the laboratory, using eggs of A. kuehniella or $S$. frugiperda and nymphs of $S$. graminum as food source, and association with artificial diet. 


\section{Material and Methods}

The experiment was conducted in acclimatized room $\left(25 \pm 1{ }^{\circ} \mathrm{C}, 70 \pm 10 \% \mathrm{RH}\right.$ and photophase of 12 hours) in the Insect Rearing Lab (LACRI) of the Brazilian Agricultural Research Corporation (EMBRAPA Maize and Sorghum) in Sete Lagoas, Minas Gerais State, Brazil.

The statistical model was a randomized complete design with six treatments and four replications, each one composed by 10 larvae of C. maculata. All larvae were obtained from adults maintained in routine rearing lab procedure fed on one week frozen eggs of A. kuehniella associated with artificial diet (Table 1) (Silva et al., 2009). One day after hatching, the larvae of $C$. maculata were isolated in $50 \mathrm{~mL}$ plastic cups, sealed with transparent acrylic lids and kept fixed in polystyrene support. The diets were offered ad libitum to the larvae of $C$. maculata according to treatment (Table 1).

After emergence, adults were sexed, weighed on an electronic scale (resolution of $0.1 \mathrm{mg}$ ) and transferred to breeding cages (glass container with $12 \mathrm{~cm}$ diameter and $18 \mathrm{~cm}$ tall) capped with plastic wrap and fed according to treatment.

Insects were observed daily to assess the stadium number $(\mathrm{n}=20)$, development period of larval, prepupal, pupal and larval-adult stages $(\mathrm{n}=20)$, larval, prepupa, pupa and larva to adult viabilities $(\mathrm{n}=40)$ in addition to adult weight and sex ratio $(\mathrm{n}=40)$.

TABLE 1. Food offered to the larvae of Coleomegilla maculata De Geer (Coleoptera: Coccinellidae) at $25 \pm 1{ }^{\circ} \mathrm{C}, 70 \pm 10 \% \mathrm{RH}$ and 12 hours photophase.

\begin{tabular}{cl}
\hline Treatments & \\
\hline T1 & Eggs of A. kuehniella (frozen for one day) \\
T2 & Eggs of A. kuehniella (frozen for one day) + artificial diet $^{1}$ \\
T3 & Eggs of $S$. frugiperda (fresh) \\
T4 & Eggs of $S$. frugiperda (fresh, without scales) \\
T5 & Eggs of $S$. frugiperda (fresh, with scales) \\
T6 & Nymphs of S. graminum \\
\hline
\end{tabular}

${ }^{1}$ Honey $(100 \mathrm{~g})$, Beer yeast (100g), Ascorbic acid (1.5g), Propionic acid $(0.5 \mathrm{~g})$, Sorbic acid $(0.25 \mathrm{~g})$, Nipagim $(0.25 \mathrm{~g})$ and water $(60 \mathrm{~g})$ 
The data were submitted to analysis of variance (ANOVA) and means compared by the Scott-Knott at 5\% probability by the program SISVAR (Ferreira, 2000).

\section{Results}

Coleomegilla maculata presented four larval stages, and each stage was not affected by the food source (Table 2). First to fourth stages takes $2.9,2.4,2.5$ and 3.3 days to complete, respectively. However, total life stage was shorter (10.2 days) when the larvae were fed on nymphs of $S$. graminum (T6). There was no significant difference in the mean larval period (11.2 days) among the other treatments.

Prepupa, pupa and larva to adult periods and respective viability were not affected by food source (Tables 3 and 4).

Sex ratio (0.51) of C. maculata was not affected by food source. However, food source did affect the insect weight (Table 5). Heavier adult females were obtained when larvae fed on fresh fall armyworm eggs (T3, T4 and T5).

TABLE 2. Development time (days) of each stage and the larval phase (mean \pm standard error) of Coleomegilla maculata De Geer (Coleoptera: Coccinellidae) with different diets at $25 \pm 1{ }^{\circ} \mathrm{C}, 70 \pm$ $10 \% \mathrm{RH}$ and 12 hours photophase.

\begin{tabular}{cccccc}
\hline \multirow{2}{*}{ Treatments } & \multicolumn{4}{c}{ Instars development time (days) } & \multirow{2}{*}{ Larval stage (days) } \\
\cline { 2 - 5 } & First & Second & Third & Fourth & \\
\hline T1 & $3.2 \pm 0.1 \mathrm{~A}$ & $2.3 \pm 0.1 \mathrm{~A}$ & $2.5 \pm 0.1 \mathrm{~A}$ & $3.3 \pm 0.1 \mathrm{~A}$ & $11.3 \pm 0.3 \mathrm{~B}$ \\
$\mathrm{~T} 2$ & $3.0 \pm 0.1 \mathrm{~A}$ & $2.6 \pm 0.1 \mathrm{~A}$ & $2.6 \pm 0.1 \mathrm{~A}$ & $3.1 \pm 0.1 \mathrm{~A}$ & $11.3 \pm 0.1 \mathrm{~B}$ \\
$\mathrm{~T} 3$ & $2.9 \pm 0.1 \mathrm{~A}$ & $2.2 \pm 0.2 \mathrm{~A}$ & $2.5 \pm 0.2 \mathrm{~A}$ & $3.5 \pm 0.1 \mathrm{~A}$ & $11.1 \pm 0.3 \mathrm{~B}$ \\
$\mathrm{~T} 4$ & $2.9 \pm 0.1 \mathrm{~A}$ & $2.3 \pm 0.1 \mathrm{~A}$ & $2.6 \pm 0.1 \mathrm{~A}$ & $3.6 \pm 0.3 \mathrm{~A}$ & $11.4 \pm 0.2 \mathrm{~B}$ \\
T5 & $2.9 \pm 0.1 \mathrm{~A}$ & $2.3 \pm 0.1 \mathrm{~A}$ & $2.5 \pm 0.1 \mathrm{~A}$ & $3.5 \pm 0.2 \mathrm{~A}$ & $11.2 \pm 0.2 \mathrm{~B}$ \\
T6 & $2.7 \pm 0.1 \mathrm{~A}$ & $2.3 \pm 0.1 \mathrm{~A}$ & $2.3 \pm 0.1 \mathrm{~A}$ & $2.9 \pm 0.1 \mathrm{~A}$ & $10.2 \pm 0.2 \mathrm{~A}$ \\
\hline CV $(\%)$ & 7.3 & 9.3 & 7.2 & 10.0 & 4.1 \\
\hline
\end{tabular}

${ }^{1}$ Means followed by the same letters in column do not differ $(\mathrm{p}<0.05)$ according to the Scott-Knott test.

Revista Brasileira de Milho e Sorgo, v.9, n.1, p. 13-26, 2010

Versão impressa ISSN 1676-689X / Versão on line ISSN 1980-6477 - http://www.abms.org.br 
TABLE 3. Development time (days) of pre-pupa, larva and pupa to adult (mean \pm standard error) of Coleomegilla maculata De Geer (Coleoptera: Coccinellidae) with different diets at $25 \pm 1{ }^{\circ} \mathrm{C}, 70 \pm$ $10 \% \mathrm{RH}$ and 12 hours photophase.

\begin{tabular}{cccc}
\hline \multirow{2}{*}{ Treatments } & Prepupa & Development time (days) & \\
& $1.0 \pm 0.0 \mathrm{~A}$ & $3.9 \pm 0.1 \mathrm{~A}$ & Larva to adult stage $^{\mathbf{P}}$ \\
\hline T1 & $1.0 \pm 0.0 \mathrm{~A}$ & $3.7 \pm 0.1 \mathrm{~A}$ & $16.2 \pm 0.4 \mathrm{~A}$ \\
T2 & $1.0 \pm 0.0 \mathrm{~A}$ & $3.5 \pm 0.1 \mathrm{~A}$ & $16.0 \pm 0.4 \mathrm{~A}$ \\
T3 & $1.0 \pm 0.0 \mathrm{~A}$ & $3.6 \pm 0.2 \mathrm{~A}$ & $15.6 \pm 0.2 \mathrm{~A}$ \\
T4 & $1.0 \pm 0.0 \mathrm{~A}$ & $3.7 \pm 0.1 \mathrm{~A}$ & $16.0 \pm 0.2 \mathrm{~A}$ \\
T5 & $1.0 \pm 0.0 \mathrm{~A}$ & $3.7 \pm 0.1 \mathrm{~A}$ & $15.9 \pm 0.3 \mathrm{~A}$ \\
T6 & 0 & 5.2 & $14.9 \pm 0.2 \mathrm{~A}$ \\
\hline CV $(\%)$ & & & 3.6 \\
\hline
\end{tabular}

${ }^{1}$ Means followed by the same letter in column do not differ $(\mathrm{p}<0.05)$ according to the Scott-Knott test.

The lowest weight of female was obtained from larvae fed on one day frozen A. kuehniella eggs. The weight of adult males was significantly lower when larvae were fed on one day frozen A. kuehniella eggs compared to the other treatments. Females were significantly heavier than males independently of food source.

\section{Discussion}

Larvae of C. maculata are characterized by elongated body with distinct abdominal segmentation and well developed legs. Close to each stadium change the insect stops eating, stands on the surface or sides of the rearing container using the last abdominal segment and then molts.
Inadequate food can increase the number of stages (Scriber \& Slansky, 1981). It seems not to be the case of food sources offered to $C$. maculata in this research. In all treatments the insect presented the same number of stages.

The same number of larval stages presented by $C$. maculata was also reported to other Coccinellidae, such as Coccinella undecimpunctata (L.) feeding on aphids species Megoura persicae (Buckton) (Hemiptera: Aphididae) and Aphis fabae (Scopoli) (Hemiptera: Aphididae) (Cabral et al., 2006) and Eriopis connexa (Germar) feeding on preys and artificial diets (Silva et al., 2009).

The period of time spent on first, second, third and fourth stages of C. maculata was 
similar among treatments. However, considering the total larval stage, shorter period of time was verified for those larvae receiving nymphs of $S$. graminum as food source. Apparently this prey could be a target in biological control program using the predator once good food quality increases the suitability of Coccinellidae larvae (Isikber \& Copland, 2002).

The longest period of time spent on the fourth stage of C. maculata, in all treatments, may be due to the fact of larvae require more nutrients at this stage to ensure pupation and metamorphosis, as reported for other insects (Scriber \& Slansky, 1981).

The viability of the larvae of C. maculata was similar between the different treatments, highlighting the fact that the eggs of $S$. frugiperda were evaluated with or without scales.
Overlapping layers of eggs and scales also did not affect the consumption or the development rate of other natural enemies with the same prey (Armas \& Ayala, 1993).

Prepupa period of C. maculata showed no difference between treatments and had values similar to those observed for $H$. convergens fed with eggs of A. kuehniella (Kato et al., 1999b) and for Cycloneda sanguinea L. (Coleoptera: Coccinellidae) with M. persicae, Megoura viciae (Buckton) (Hemiptera: Aphididae), A. fabae or Aphis gossypii (Glover) (Hemiptera: Aphididae) (Isikber \& Copland, 2002)

The initial phase of prepupa of $C$. maculata was set when the larvae stopped feeding and set by the last abdominal segment in various parts of the rearing container. When touched, pre-pupa moved sharply. Similar

TABLE 4. Viability (\%) of the larval, prepupal, pupal and larvae to adult (mean \pm standard error) of Coleomegilla maculata De Geer (Coleoptera: Coccinellidae) with different diets at $25 \pm 1{ }^{\circ} \mathrm{C}, 70 \pm$ $10 \% \mathrm{RH}$ and 12 hours photophase.

\begin{tabular}{ccrrc}
\hline \multirow{2}{*}{ Treatments } & \multicolumn{4}{c}{${\text { Viability }(\%)^{1}}^{1}$} \\
\cline { 2 - 5 } & \multicolumn{1}{l}{ Larval } & Prepupal & \multicolumn{1}{c}{ Pupal } & Larva to adult stage \\
\hline T1 & $100.0 \pm 0.0 \mathrm{~A}$ & $90.0 \pm 5.8 \mathrm{~A}$ & $93.7 \pm 6.2 \mathrm{~A}$ & $85.0 \pm 9.6 \mathrm{~A}$ \\
T2 & $100.0 \pm 0.0 \mathrm{~A}$ & $97.5 \pm 2.5 \mathrm{~A}$ & $100.0 \pm 0.0 \mathrm{~A}$ & $97.5 \pm 2.5 \mathrm{~A}$ \\
T3 & $95.0 \pm 2.9 \mathrm{~A}$ & $100.0 \pm 0.0 \mathrm{~A}$ & $97.4 \pm 2.6 \mathrm{~A}$ & $91.9 \pm 2.7 \mathrm{~A}$ \\
T4 & $92.5 \pm 4.8 \mathrm{~A}$ & $100.0 \pm 0.0 \mathrm{~A}$ & $100.0 \pm 0.0 \mathrm{~A}$ & $92.5 \pm 4.8 \mathrm{~A}$ \\
T5 & $95.0 \pm 8.5 \mathrm{~A}$ & $100.0 \pm 0.0 \mathrm{~A}$ & $100.0 \pm 0.0 \mathrm{~A}$ & $95.0 \pm 2.9 \mathrm{~A}$ \\
T6 & $97.5 \pm 2.5 \mathrm{~A}$ & $94.9 \pm 2.4 \mathrm{~A}$ & $97.3 \pm 2.4 \mathrm{~A}$ & $94.2 \pm 3.3 \mathrm{~A}$ \\
\hline CV $(\%)$ & 5.7 & 5.2 & 6.0 & 10.7 \\
\hline
\end{tabular}

${ }^{1}$ Means followed by the same letter in column do not differ $(\mathrm{p}<0.05)$ according to the Scott-Knott test.

Revista Brasileira de Milho e Sorgo, v.9, n.1, p. 13-26, 2010

Versão impressa ISSN 1676-689X / Versão on line ISSN 1980-6477 - http://www.abms.org.br 
TABLE 5. Sexual ratio (\%) and adult weight (mg) (mean \pm standard error) of Coleomegilla maculata De Geer (Coleoptera: Coccinellidae) originated from larvae with different diets at $25 \pm 1{ }^{\circ} \mathrm{C}, 70 \pm$ $10 \% \mathrm{RH}$ and 12 hours photophase.

\begin{tabular}{|c|c|c|c|c|}
\hline \multirow{2}{*}{ Treatments } & \multirow{2}{*}{ Sexual ratio $(\%)^{1}$} & \multicolumn{3}{|c|}{ Weight (mg) ${ }^{1}$} \\
\hline & & Females & Males & Mean \\
\hline $\mathrm{T} 1$ & $0.45 \pm 0.03 \mathrm{~A}$ & $13.3 \pm 0.5 \mathrm{~A}$ & $9.8 \pm 0.3 \mathrm{~A}$ & 11.6 \\
\hline $\mathrm{T} 2$ & $0.48 \pm 0.04 \mathrm{~A}$ & $15.5 \pm 0.5 \mathrm{~B}$ & $12.0 \pm 0.3 \mathrm{~B}$ & 14.9 \\
\hline $\mathrm{T} 3$ & $0.54 \pm 0.07 \mathrm{~A}$ & $17.8 \pm 0.2 \mathrm{C}$ & $12.4 \pm 0.5 \mathrm{~B}$ & 15.1 \\
\hline $\mathrm{T} 4$ & $0.55 \pm 0.06 \mathrm{~A}$ & $17.6 \pm 0.1 \mathrm{C}$ & $12.4 \pm 0.1 \mathrm{~B}$ & 14.9 \\
\hline $\mathrm{T} 5$ & $0.48 \pm 0.04 \mathrm{~A}$ & $17.3 \pm 0.3 \mathrm{C}$ & $12.3 \pm 0.3 \mathrm{~B}$ & 14.8 \\
\hline T6 & $0.54 \pm 0.04 \mathrm{~A}$ & $15.2 \pm 0.2 \mathrm{~B}$ & $11.9 \pm 0.1 \mathrm{~B}$ & 13.6 \\
\hline Mean & $0.51 \pm 0.02$ & $16.4 \pm 0.3 \mathrm{a}$ & $11.9 \pm 0.2 \mathrm{~b}$ & \\
\hline CV (\%) & 18.7 & 4.3 & 4.6 & \\
\hline
\end{tabular}

${ }^{1}$ Means followed by the same letters in column do not differ $(\mathrm{p}<0.05)$ according to the Scott-Knott test.

behavior was also observed in Olla v-nigrum (Mulsant) (Coleoptera: Coccinellidae) (Kato et al., 1999a).

Prepupa stage of C. maculata showed different pattern from that reported for $S$. sinvanodulus because the prepupa of this species was seen when the larvae stopped feeding and released the anal region liquids in large numbers and became still for one to two days ( $\mathrm{Lu}$ et al., 2002), a fact also observed for $C$. maculata. However, some larvae of $S$. sinvanodulus after the period of immobility, began to crawl, forming a pupa after this period of creep, and a high percentage of those that died exhibited this behavior (Lu et al., 2002). This behavior of $S$. sinvanodulus was associated with a mechanism of the larvae of this predator to seek suitable sites for feeding or protection for pupation ( $\mathrm{Lu}$ et al., 2002).

Coleomegilla maculata is a holometabolous insect, whose pupa is classified as drawn up by not showing appendages applied on the body, but free and visible. The pupa of this species had light coloring and darkening slowly acquiring spots of the sub family Coccinellinae (Hodek, 1973). The larval and pupal viability were similar between treatments, showing that the foods offered were sufficient to meet their nutritional needs.

Soon after the emergence, the adults of C. maculata remained motionless, with color 
changing gradually from pale, then pink hue, darkening to become red, with black spots.

The sex ratio of $C$. maculata was similar to other Coccinellidae, as $H$. convergens, Cryptolaemus montrouzieri (Mulsant), Delphastus pusillus (LeConte), Harmonia axyridis (Pallas), Lindorus lophanthae (Blais) and S. punctillum (Heimpel \& Lundgren, 2000).

Females had higher weight than males, which seems to be a pattern of Coccinellidae (Kato et al., 1999a; Silva et al., 2009). The greater weight of females of $C$. maculata in all treatments suggests that these may be distinguished from male conspecifics by their weight, as reported for $H$. convergens and Coccinella septempunctata (L.) (Coleoptera: Coccinellidae) on Myzus persicae nicotianae (Sulzer) (Hemiptera: Aphididae) (Katsarou et al., 2005).

Female fecundity is determined by the insect oogenesis, a physiological process regulated by the availability of nutrients in the body of the insect (Wheeler, 1996). Any factor that affects the incorporation of nutrients can affect oogenesis and hence the rate of laying insects. Generally, larger females are more fecund than smaller ones, as reported for $C$. sanguinea, which is heavier and fruitful with Toxoptera citricida (Kirkaldy) (Hemiptera: Aphididae) than with Aphis spiraecola (Patch) (Hemiptera: Aphididae) (Michaud, 2000).

The greater weight of adult C. maculata, which fed on eggs of $A$. kuehniella (frozen for a day) alone or associated with artificial diet, and eggs of $S$. frugiperda, shows that these foods offer the best way for the development of predator than nymphs of $S$. graminum. This is an important factor because the weight is indicative of the nutrients and energy stored, which may influence copulation, flight dispersal and fecundity (Omkar et al., 2006). In fact, Coccinellidae predators need food nutritional supplementation, such as pollen and nectar, which sustain metabolism and reproductive development of certain species (Hagen, 1962; Hodek, 1967, 1973). Specifically, C. maculata showed faster development and higher survival rates when fed on a mixture of $R$. maidis and corn pollen than when fed on only one of these sources (Cottrell \& Yeargan, 1998; Lundgren \& Wiedenmann, 2004).

Michaud \& Jyoti (2008) reported the consequences of changing the diet of larvae and adult $C$. maculata. Females fed on eggs of A. kuehniella that had their diet replaced by nymphs of $S$. graminum had increased its fecundity compared to females which continued eating only eggs from $A$. kuehniella. Also, the predator can survive either on egg or young larvae of S. frugiperda (Pereira, 1997; Hoballah et al., 2004).

Eggs of A. kuehniella (one day of freezing) or $S$. frugiperda and nymphs of S. graminum were appropriate for different developmental stages of C. maculata, which facilitates rearing in the laboratory. Although stored frozen eggs can be used as a food source for rearing insect predators with initial lower

Revista Brasileira de Milho e Sorgo, v.9, n.1, p. 13-26, 2010

Versão impressa ISSN 1676-689X / Versão on line ISSN 1980-6477 - http://www.abms.org.br 
production cost than with fresh eggs, one should consider the balance between nutritional quality of the eggs of $A$. kuehniella and storage period of time (Mohaghegh \& Amir-Maafi, 2007).

Coleomegilla maculata has great potential use for biological control of $S$. frugiperda and $S$. graminum, due to its large feeding plasticity and ability to adapt to different foods, which is interesting for the management of these pests in maize and sorghum. However, to be used in field, laboratory massal rearing will be needed. One of the difficulties in rearing Coccinellidae predator in the laboratory is to obtain their natural diet throughout the year, particularly natural hosts such as aphids, whose populations in the field usually have a nature ephemeral and unpredictable in time and space. However the use of A. kuehniella eggs as an alternative food source has proven favorable in the replacement of several natural preys of Coccinellidae. This insect can be easily and cheaply reared in the lab.

\section{Acknowledgments}

To "Conselho Nacional de Desenvolvimento Científico e Tecnológico (CNPq)", "Coordenação de Aperfeiçoamento de Pessoal de Nível Superior (CAPES)" and "Fundação de Amparo à Pesquisa do Estado de Minas Gerais (FAPEMIG)" for Grant and financial funds.

\section{References}

ANDOW, D. A.; RISCH, S. J. Predation in diversified agroecosystems: relations between a coccinellid predator Coleomegilla maculata and its food. Journal of Applied Ecology, Oxford, v. 22 , p. $357-372,1985$.

ARMAS, J. L.; AYALA, J. L. Parasitic behavior, biology, reproduction and field utilization of Telenomus sp. a native parasitoid of Spodoptera frugiperda in Cuba. Trichogramma News, Braunschweig, v. 7, p. 24, 1993.

ATTALLAH, Y. H.; NEWSON, L. D. Ecological and nutritional studies on Coleomegilla maculata De Geer (Coleoptera: Coccinellidae). I. The development of an artificial diet and laboratory rearing technique. Journal of Economic Entomology, College Park, v. 59, p. 1173-1179, 1966.

CABRAL, S.; SOARES, A. O.; MOURA, R.; GARCIA, P. Suitability of Aphis fabae, Myzus persicae (Homoptera: Aphididae) and Aleyrodes proletella (Homoptera: Aleyrodidae) as prey for Coccinella undecimpunctata (Coleoptera: Coccinellidae). Biological Control, San Diego, v. 39, p. 434-440, 2006.

COTTRELL, T. E.; YEARGAN, K. V. Effect of pollen on Coleomegilla maculata (Coleoptera: Coccinellidae), population density, predation, and cannibalism in sweet corn. Environmental Entomology, College Park, v. 27, p. 1402-1410, 1998. 
CRUZ, I.; VENDRAMIM, J. D. Não preferência como mecanismo de resistência de sorgo ao pulgão-verde. Pesquisa Agropecuária Brasileira, Brasília, DF, v. 24, p. 329-335, 1989.

FERREIRA, D. F. Sistema SISVAR para análises estatísticas: manual de orientação. Lavras: Universidade Federal de Lavras/ Departamento de Ciências Exatas, 2000. 37 p.

FONSECA, A. R.; CRUZ, I.; CARVALHO, C. F.; SOUZA, B. Avaliação de genótipos de sorgo para resistência ao Rhopalosiphum maidis (Fitch, 1856) (Hemiptera: Aphididae) em teste de livre escolha. Revista Brasileira de Milho e Sorgo, Sete Lagoas, v. 5, p. 26-36, 2006.

HAGEN, K. S. Biology and ecology of predaceous Coccinellidae. Annual Review of Entomology, Palo Alto, v. 7, p. 289-326, 1962.

HEIMPEL, G. E.; LUNDGREN, J. G. Sex ratios of commercially reared biological control agents. Biological Control, San Diego, v. 19, p. 77-93, 2000.

HOBALLAH, M. E.; DEGEN, T.; BERGVINSON, D.; SAVIDAN, A.; TAMÒ, C.; TURLINGS, T. C. J. Occurrence and direct control potential of parasitoids and predators of the fall armyworm (Lepidoptera: Noctuidae) on maize in the subtropical Lowlands of Mexico. Agricultural and Forest Entomology, Oxford, v. 6, p. 83-88, 2004.

HODEK, I. Bionomics and ecology of predaceous Coccinellidae. Annual Review of Entomology, Palo Alto, v. 12, p. 79-104, 1967.
HODEK, I. Biology of Coccinellidae. Prague: Academy of Sciences, 1973. 260 p.

ISIKBER, A. A.; COPLAND, M. J. W. Effects of various aphid foods on Cycloneda sanguinea. Entomologia Experimentalis et Applicata, Dordrecht, v. 102, p. 93-97, 2002.

KARILUOTO, K. T.; JUNNIKKALA, E.; MARKKULA, M. Attempts at rearing Adalia bipunctata L. (Col. Coccinellidae) on different artificial diets. Annales Entomologici Fennici, Helsinki, v. 42, p. 91-97, 1976.

KARILUOTO, K. T. Survival and fecundity of Adalia bipunctata (Coleoptera: Coccinellidae) and some other predatory insect species on an artificial diet and a natural prey. Annales Entomologici Fennici, Helsinki, v. 46, p. 101$106,1980$.

KATO, C. M.; AUAD, A. M.; BUENO, V. H. P. Aspectos biológicos e etológicos de Olla v-nigrum (Mulsant, 1866) (Coleoptera: Coccinellidae) sobre Psylla sp. (Homoptera: Psyllidae). Ciência e Agrotecnologia, Lavras, v. 23, p. 19-23, 1999a.

KATO, C. M.; BUENO, V. H. P.; MORAES, J. C.; AUAD, A. M. Criação de Hippodamia convergens Guérin-Méneville (Coleoptera: Coccinellidae) em ovos de Anagasta kuehniella (Zeller) (Lepidoptera: Pyralidae). Anais da Sociedade Entomológica do Brasil, Jaboticabal, v. 28, p. 455-459, 1999 b.

KATSAROU, I.; MARGARITOPOULOS, J. T.; TSITSIPIS, J. A.; PERDIKIS, D. C.; 
ZARPAS, K. D. Effect of temperature on development, growth and feeding of Coccinella septempunctata and Hippodamia convergens reared on the tobacco aphid, Myzus persicae nicotianae. BioControl, Dordrecht, v. 50, p. 565-588, 2005.

LU, W.; SOUPHANY, P.; MONTGOMERY, M. E. Descriptions of immature stages of Scymnus (Neopullus) sinuanodulus Yu and Yao (Coleoptera: Coccinellidae) with notes on life history. Coleopterists Bulletin, Washington, v. 56, p. 127-141, 2002.

LUNDGREN, J. G.; WIEDENMANN, R. N. Nutritional suitability of corn pollen for the predator Coleomegilla maculata (Coleoptera: Coccinellidae). Journal of Insect Physiology, Oxford, v. 50, p. 567-575, 2004.

MAIA, W. J. M. S.; CRUZ, I.; CARVALHO, C. F.; SOUZA, B.; WAQUIL, J. M.; VON PINHO, R. G.; CARVALHO, S. P.; MAIA, T. J. A. F.; LOUREIRO, I. Efeito do estádio fenológico do milho (Zea mays L.) sobre a infestação pelo pulgão Rhopalosiphum maidis (Fitch, 1856). Revista Brasileira de Milho e Sorgo, Sete Lagoas, v. 4, p. 308-315, 2005.

MATSUKA, M.; WATANABE, M.; NIIJIMA, $K$. Longevity and oviposition of vedalia beetles on artificial diets. Environmental Entomology, College Park, v. 11, p. 816-819, 1982.

MICHAUD, J. P. Development and reproduction of ladybeetles (Coleoptera: Coccinellidae) on the citrus aphids Aphis spiraecola Patch and Toxoptera citricida (Kirkaldy) (Homoptera:
Aphididae). Biological Control, San Diego, v. 18, p. 287-297, 2000.

MICHAUD, J. P.; JYOTI, J. L. Dietary complementation across life stages in the poliphagous lady beetle Coleomegilla maculata. Entomologia Experimentalis et Applicata, Dordrecht, v. 126, p. 40-45, 2008.

MOHAGHEGH, J.; AMIR-MAAFI, M. Reproduction of the predatory stinkbug Andrallus spinidens (F.) (Heteroptera: Pentatomidae) on live and frozen prey. Applied Entomology and Zoology, Tokyo, v. 42, p. 15-20, 2007.

MUNYANEZA,J.; OBRYCKI,J.J.Development of three populations of Coleomegilla maculata (Coleoptera: Coccinellidae) feeding on eggs of Colorado potato beetle (Coleoptera: Chrysomelidae). Environmental Entomology, College Park, v. 27, p. 117-122, 1998.

OMKAR; MISHRA, G.; SINGH, S. K. Optimal number of matings in two aphidophagous ladybirds. Ecological Entomology, Oxford, v. 31, p. 1-4, 2006.

PEREIRA, C. J. Respuesta agregativa de adultos de Coleomegilla maculata a la densidad y distribucion de los huevos del cogollero del mayus. Bioagro, Barquisimeto, v. 9, p. 35-42, 1997.

RACIOPPI, J. V.; BURTON, R. L.; EIKENBARY $\mathrm{R}$. The effects of various oligidic synthetic diets on the growth of Hippodamia convergens. Entomologia Experimentalis et Applicata, Dordrecht, v. 30, p. 68-72, 1981. 
RISCH, S. J.; ANDOW, D.; ALTIERI, M. A. Agroecosystem diversity and pest control: data, tentative conclusions, and new research directions. Environmental Entomology, College Park, v. 12, p. 625-629, 1983.

SCRIBER, J. M.; SLANSKY, F. J. The nutritional ecology of immature insects. Annual Review of Entomology, Palo Alto, v. 26, p. 183-211, 1981.

SILVA, R. B.; ZANUNCIO, J. C.; SERRÃO, J. E.; LIMA, E. R.; FIGUEIREDO, M. L. C.; CRUZ, I. Suitability of different artificial diets for development and survival of stages of predaceous ladybird beetle Eriopis connexa (Coleoptera: Coccinellidae). Phytoparasitica, Bet Dagan, v. 37, p. 115-123, 2009.
STOETZEL, M. B.; MilleR, G. L. Aerial feeding aphids of corn in the United States with reference to the root-feeding Aphis maidiradicis (Homoptera: Aphididae). Florida Entomologist, Gainesville, v. 84, p. 83-98, 2001.

THOMPSON, S. N. Nutrition and culture of entomophagous insects. Annual Review of Entomology, Palo Alto, v. 44, p. 561-592, 1999.

WHEELER, D. The role of nourishment in oogenesis. Annual Review of Entomology, Palo Alto, v. 41, p. 407-431, 1996. 